Ministerstwo Nauki

i Szkolnictwa Wyższego

Digitalizacja archiwalnych numerów czasopisma naukowego Analecta Cracoviensia 1-24 (1969-1992)

i ich publikacja w otwartym dostępie - zadanie finansowane w ramach umowy 672/P-DUN/2017 ze środków

Ministra Nauki i Szkolnictwa Wyższego przeznaczonych na działalność upowszechniającą naukę

KS. MARIAN JAWORSKI

\title{
PRĄDY FILOZOFICZNE U PODSTAW NOWEJ TEOLOGII
}

\section{PROBLEM UDZIAEU FILOZOFII W TEOLOGII}

Rozważanie tematu sformułowanego w tytule artykułu wymaga wstępnego naświetlenia - przynajmniej skrótowo - bardziej pierwotnego zagadnienia: stosunku pomiędzy filozofią i teologią w ogóle, względnie udziału filozofii $w$ teologii. Zagadnienia tego nie można pominąć zwłaszcza obecnie, kiedy teza o wzajemnym przenikaniu się filozofii i teologii jest kwestionowana nie tylko wśród teologów protestanckich, ale także wśród teologów katolickich.

Zasada, którą głosił Kościół Katolicki stale w oparciu o naukę św. Pawła o wierze jako obsequium rationale - jak dobrze wiadomo to konieczność refleksji rozumowej nad wiarą. Innymi słowy jest to konieczność teologii jako wysiłku rozumu oświeconego wiarą, albo dokładniej dzieło wiary korzystającej $z$ usług rozumu: fides quaerens intellectum ${ }^{1}$. Tak pojęta teologia jest „wiedzą", a jeżeli uwzględni się charakter refleksji rozumowej, która tutaj ma udział przede wszystkim, to śmiało można powiedzieć, że ,wierzący stał się filozofem" 2. Krótko więc można stwierdzić, że według stanowiska przedstawionego wyżej, teologia konstytuuje się przy udziale filozofii. Wskazuje zresztą na to sama nazwa ,teologia" ${ }^{3}$.

Zasada ta - jak zostało już zaznaczone - kwestionowana jest dzisiaj, czemu daje wyraz list Kongregacji dla nauczania katolickiego z 20. I. 1972 r. skierowany do Biskupów w sprawie nauczania filozofii 106.

1 A. Dondeyne, Foi Chrétienne et Pensée Contemporaine, Louvain-Paris, 1961,

2 Por. m. in. F. M. Genuyt OP, Tajemnica Boga, w: Tajemnica Boga, Poznań-Warszawa-Lublin 1967, 222.

3 M. Nédoncelle, Teologia a filozofia czyli o metamorfozach stużebnicy, "Concilium", Międzynarodowy Przegląd Teologiczny, Poznań-Warszawa 1965/6, 455. - Więcej na ten temat por. Ks. M. Jaworski, Inspiracje soborowe $w$ filozofii, w: Myśl posoborowa $w$ Polsce, Warszawa 1970, 36-42; tenże, Teologia a antropologia, „Analecta Cracoviensia”, 3 (1971) 53. 
w Seminariach. Czytamy tam m. in.: ,sami teologowie uważają czasem filozofię za rzecz zbędną, a zatem szkodę przynoszącą kształceniu kapłana. Mniemają oni, że czystość ewangelicznego przekazu została skażona w ciągu dziejów przez wprowadzenie greckiej spekulacji do świętych nauk. Sądzą, iż filozofia scholastyczna obciążyłaby teologię spekulatywną mnóstwem problemów pozornych; wobec tego nauki teologiczne winno się uprawiać metodą historyczną".

W zakwestionowaniu filozofii dla teologii, spośród wielu przyczyn warunkujących tego rodzaju stanowisko, na które zwraca uwagę wspomniany list Kongregacji, pragnę zwrócić od siebie uwagę na dwa czynniki, które zdają się tutaj odgrywać dużą rolę: 1-o, w zakwestionowaniu tej zasady miesza się najpierw charakter względnie sposób udziału filozofii w teologii z udziałem filozofii w ogóle. Mianowicie, z niewłaściwego zastosowania filozofii w refleksji teologicznej wyciąga się fałszywy wniosek o nieużyteczności względnie szkodliwości filozofii w teologii, 2-o, refleksję filozoficzną pojmuje się mniej lub bardziej idealistycznie jako wytwór samego rozumu, całkowicie niezależny od rzeczywistości, który to wytwór sam ze siebie nie tylko że nie pozostaje w żadnym związku z Objawieniem, ale któremu ponadto chce się podporządkować Objawienie (typowy przykład tego rodzaju stanowiska mamy w XIX w. w filozofii idealistycznej). W tym ujęciu refleksji filozoficznej nie może być też mowy o tzw. objawieniu naturalnym. Jak więc można zauważyć, już w tego rodzaju zakwestionowaniu użyteczności filozofii dla teologii tkwi określone stanowisko filozoficzne. W protestantyzmie neguje się zaś filozofię przede wszystkim z punktu widzenia religijnego ${ }^{4}$.

Wypada jednak stwierdzić: problemem nie jest udział filozofii w teologii, ale problemem jest właściwe użycie filozofii w teologii, którego nie można jednoznacznie raz na zawsze wyznaczyć ze względu na zmieniającą się i rozwijającą formę refleksji filozoficznej ${ }^{5}$. Nie można wykluczyć udziału filozofii w teologii. Słowo Boże odniesione jest bowiem na rozumienie ludzkie. Jeśli ma być przyjęte, może być przyjęte na sposób i w kategoriach ludzkiej myśli ${ }^{6}$. Przyjęcie Objawienia dokonuje się zawsze w kontekście wiedzy, jaką człowiek ma o sobie i o świecie, a więc w świetle najbardziej ogólnie pojętego ,światopoglądu filozoficznego" nie koniecznie w pełni refleksyjnego ${ }^{7}$. Z tego udziału teolog musi

4 Por. E. Gilson, Chrystianizm a filozofia, Warszawa 1958, 11.

5 Por. Y. Congar: Teologia na Soborze, „Więź”, 2 (1967) 31-43; Wiara i teologia, w: Tajemnica Boga, 141.

6 Bernhard Welte, Heilsverständnis, Philosophische Untersuchung einiger Vorausstzungen zum Verständnis des Christentums, Freiburg-Basel/Wien 1966, 22 i $48-49$.

7 K. Rahner, Philosophie und Theologie, w: Schriften zur Theologie VI, Einsiedeln 1965, 93-94; tenże: Hörer des Wortes, München 1963, szczególnie r. 14: Religiosphilosophie und Theologie, $205 \mathrm{n}$. 
zdawać sobie świadomie sprawę, jeśli nie chce się opierać na niekontrolowanych założeniach i błędnie tłumaczyć przekaz wiary ${ }^{8}$. Na tego rodzaju udział filozofii $w$ teologii zwraca uwagę cytowany list Kongregacji: „rozporządzając dzisiaj o wiele bardziej pewnymi elementami niż dawniej, teolog spekulatywny winien poddać rozumowej krytyce pojęcia i kategorie, w których Objawienie się wyraża. [...] W sposób szczególny będzie musiał korzystać z pomocy zdrowej filozofii, która wniesie swój wkład refleksji bądź to w założenia bądź to we wnioski poznawcze dyscyplin szczegółowych. Egzegeza, historia etc. często już w swych preliminariach dokonują implicite jakiegoś wyboru filozoficznego i zdrowa filozofia będzie tu szczególnie niezbędna dla unaocznienia i krytycznej oceny takiego wyboru - pomyślmy tu o metodzie egzegetycznej Bultmanna - a wszystko to przy poszanowaniu danych Objawienia.

Tego rodzaju wzajemne oddziaływanie nauk, filozoficznej i teologicznej, którego korzenie tkwią głęboko w samej ich naturze uwydatnia się jeszcze w sytuacji, jaka w ostatnich latach wytworzyła się na polu teologii. Teologia stara się dziś otworzyć na nowy wymiar — historyczny, antropologiczny, egzystencjalny, personalistyczny; usiłuje rozwijać nowe aspekty - psychologiczny, społeczno-polityczne, ortopraktyczne itd. Zabiega ponadto o udoskonalenie swych własnych metod w kierunku hermeneutycznym. Wyrasta stąd nowa problematyka, która czasem sięga do samych podstaw teologicznego poznania, na przykład gdy idzie o możliwość definicji dogmatycznych posiadających trwałą wartość, co w konsekwencji pociąga za sobą potrzebę nowego oświetlenia i pogłębienia takich pojęć jak prawda, pojemność i granice ludzkiego poznania, postęp, ewolucja, przyroda i osoba ludzka, prawo naturalne, przypisywalność działań moralnych etc."

\section{RÓŻNORODNOŚĆ I ROZWÓJ REFLEKSJI FILOZOFICZNEJ A TEOLOGIA}

Jeżeli założymy wzajemne przenikanie się filozofii i teologii, o którym mowa wyżej, wewnętrzny udział filozofii $\mathrm{w}$ teologii ${ }^{9}$ i uwzględnimy $1^{\circ}$ pluralizm filozoficzny w postaci różnorodnych szkół i kierunków filozoficznych i $2^{\circ}$ rozwój refleksji filozoficznej, to stanie się dla nas zrozumiałe $1^{\circ}$ tworzenie się różnych kierunków teologicznych i $2^{\circ}$ postępujące rozumienie wiary w oparciu o autentyczną refleksję filozoficzną.

Zwykle, zwłaszcza obecnie, akcentuje się pluralizm teologiczny, będący zastosowaniem refleksji teologicznej różnych, współczesnych kierunków

8 B. Welte, dz. cyt., 22.

9 René Virgoulay, Foi et Critique, La Philosophie de la Religion et la théologie, „Recherches de Science Religieuse”, 54 (1966) 509. 
filozoficznych. Historia zaś teologii ukazuje nam pluralizm teologiczny w perspektywie historycznej. Wielka synteza teologiczna św. Tomasza, która twórczo nawiązała do założeń filozofii Arystotelesa, stanowiła niewątpliwie rewolucję duchową w chrześcijaństwie, w którym całkowicie panowała dotąd teologia augustyniańska posługująca się jako narzędziem filozofią platońską względnie neoplatońską. Rewolucja ta byłaby nie do pomyślenia, gdyby filozoficzna myśl Arystotelesa nie wtargnęła w oświecone sfery ówczesnego świata i w dużym stopniu nie stała się ich światopoglądem filozoficznym. Podobnie zależność pomiędzy filozoficzną refleksją a teologią $\mathrm{w}$ mniejszym lub większym stopniu zachodzi $\mathrm{w}$ okresach późniejszych i oczywiście w naszych czasach.

Wydaje się jednak, że należy bardziej podkreślić, gdy się ma na uwadze prawdę rzeczy, lepsze rozumienie wiary, które się dokonuje w czasie dzięki rozwojowi reflekcji filozoficznej. Bez uwzględnienia tego momentu, to co jest najbardziej zasadnicze, a mianowicie rozwój doktryny chrześcijańskiej, zostanie usunięty w cień. Tymczasem nie chodzi przecież ani o żaden historycznie dokonany system interpretacji chrześcijaństwa, ani o nowość zrywającą $z$ przeszłością, ale o coraz lepsze rozumienie, o pełniejsze posiadanie prawdy. $\mathrm{Na}$ tego rodzaju znaczenie refleksji filozoficznej dla teologii zwraca uwagę soborowy Dekret Optatam totius ${ }^{10}$. - Swiadomość wpływu refleksji filozoficznej na lepsze rozumienie wiary w płaszczyźnie teologicznej pozwala nam także na właściwe ustosunkowanie się do tych zmian, których obecnie jesteśmy świadkami w teologii. Aby unaocznić ten wpływ refleksji filozoficznej na postępujące rozumienie wiary, uwzględnijmy tylko przykładowo, czego dokonała refleksja filozoficzna na temat historii, historyczności bytu człowieka. Rozwój refleksji filozoficznej dotyczący historii sprawił, że wypowiedzi, czy to zawarte w Piśmie św., czy w rozstrzygnięciach Soboru - jako przynależące do określonej epoki historycznej, która wyznaczała ich sposób pytania, myślenia i wyrażania się - zaczęto rozumieć na podstawie im właściwego kontekstu historycznego. Wynikające stąd historyczno-krytyczne rozumienie tekstów prowadziło nieraz do ujęć innych niż to było zwyczajnie dotąd przyjęte ${ }^{11}$. Przede wszystkim jednak nie pozwalało na bezpośrednie przenoszenie różnych wypowiedzi historycznie uwarunkowanych na jedną płaszczyznę czysto abstrakcyjnych formuł. Tego rodzaju refleksja filozoficzna postawiła jednak na nowo problem teologicznego rozumienia, poznania; sięgający - jak to zaznacza list Kongregacji - cytuję jeszcze raz ten ustęp - samych podstaw teologicznego poznania. Chodzi bowiem o możliwość definicji dogmatycznych, posiadających trwałą wartość, co $\mathrm{w}$ konsekwencji pociąga za sobą

10 Por. więcej na ten temat: M. Jaworski, Inspiracje soborowe..., 36-37.

11 Por. B. Welte, dz. cyt., $17-20$. 
potrzebę nowego oświetlenia takich pojęć jak prawda, pojemność i granice ludzkiego poznania [...]". Dodajmy od siebie, że odkrycie historycznego wymiaru egzystencji ludzkiej postawiło w całej ostrości problem, czy prawda chrześcijaństwa jest tylko ,losem” historycznego bytowania, jest zrelatywizowana do procesu oddziaływania samej historii (Gadamar), czy też możliwa jest prawda ponad-historyczna chrześcijaństwa, bezwarunkowo ważna, do której człowiek dochodzi w trakcie swej historycznej egzystencji. - Wiadomo też do jakich kryzysów problematyka ta doprowadziła na przestrzeni ostatnich stu lat i że dzisiaj jeszcze trudno mówić - ich całkowitym przezwyciężeniu. Niemniej można już stwierdzić, że dzisiaj lepiej umiemy wytłumaczyć i pogodzić ,rozwój doktrynȳ chrześcijańskiej" z roszczeniem Chrześcijaństwa do stanowienia jednej niezmiennej prawdy. Lepiej rozumiemy stwierdzenie, że prawdę Bożą poznajemy w świecie i poprzez świat (poprzez kategorie wzięte ze świata). Jeżeli jednak takie jest podstawowe prawo poznania rzeczywistości Bożych, a poznanie rzeczywistości naszej nie jest nigdy zakończone, że ciągle mamy do czynienia z procesem jej odsłaniania, że żadna prawda nie jest na tyle doskonała i absolutna, by uniemożliwiała stawianie dalszych pytań, to tego rodzaju nasze ludzkie poznanie musi warunkować stale też postępujące poznanie prawdy Bożej, prawdy Chrześcijaństwa. Nie oznacza to zmienności, relatywizmu prawdy. Chodzi o prawdę „rzeczy w sobie", którą w trakcie procesu historycznego coraz lepiej odkrywamy ${ }^{12}$. Nowe sytuacje historyczne prowadzą nas do coraz nowych odsłonięć tej samej prawdy, prowadzą do ubogacenia sensu (czasami do częściowego zapomnienia już posiadanego), pozostającego jednak (tak powinno być) w spójności z pierwotnie ważnie ustalonym sensem ${ }^{13}$. (Dla ilustracji tego można wziąć pod uwagę dawne definicje i określenia Kościoła i określenie Kościoła przede wszystkim jako ludu Bożego, tak jak ono zostało przedstawione w nauce Soboru Watykańskiego II).

- Po tym przedstawieniu udziału filozofii w teologii i wpływie refleksji filozoficznej na postępujące rozumienie teologiczne, będę się starał ukazać - w dużym tylko zarysie - jak wygląda udział filozofii w kształtowaniu współczesnego obrazu teologii (częściowo zostało już to ukazane wyżej, przy omawianiu filozoficznej problematyki istnienia ludzkiego).

12 Por. E. Coreth, Grundfragen der Hermeneutik, Freiburg-Basel-Wien 1969, 166 n., 171, 188 n., 193 n., 211. - Więcej na ten temat piszę w art. Granice pluraIizmu w nowej interpretacji dogmatów (Chrześcijańskie doświadczenie religijne jako norma interpretacji), „Analecta Cracoviensia” 5 (1973).

13 Por. w tym względzie: Max Scheler, Vom Ewigen im Menschen, Berlin 1933, $445 \mathrm{n}$. 
III. OBECNOSC NIEKTÓRYCH KIERUNKÓW FILOZOFICZNYCH WE WSPÓECZESNEJ TEOLOGII

\section{Orientacja antropologiczna}

Oblicze współczesnej teologii kształtuje w dużej mierze kierunek antropologiczny (filozofia podmiotu), znamionujący nowożytną i współczesną myśl filozoficzną. Przyjmuje on różne odmiany, jak np. fenomenologia, egzystencjalizm, strukturalizm.

O zmianie tej w teologii pisze i ocenia ją następująco Congar: „Od wieków, zwłaszcza od epoki wielkich Scholastyków, którzy przedstawili tak doskonałe opracowanie doktryny świętej, że wydawało się ono definitywnym, teologia $\mathrm{z}$ powodzeniem posługiwała się w swych sformułowaniach kategoriami ontologicznymi. Wychodząc od Objawienia starała się ona kontemplować i określać istotę [l'en soi] Boga i Chrystusa, czyli to, czym oni są sami w sobie". (Ten sposób uprawiania teologii staje się zrozumiały - dodajmy - gdy się uwzględni, że żyli oni, działali w epoce odzyskania wielkich systemów metafizycznych starożytności, przede wszystkim Arystotelesa). — Jaką sytuację intelektualną mamy obecnie? „,W przeciwieństwie do filozofii antycznych [dzisiejsza myśl filozoficzna] nie szuka już jakiegoś całościowego ujęcia i tłumaczenia świata $w$ kategoriach ontologicznych (podkr. moje), lecz jest refleksją nad istnieniem i losem ludzkim. Dzięki temu rozpoczyna ona, czy też otwiera ponownie pewien rozdział myśli ludzkiej, poświęcony bardzo owoconym rozważaniom nad stosunkami międzyosobowymi (ontologia intersubiektywności jest czymś różnym od subiektywizmu). Filozofia tego rodzaju przyczynia się do rozwoju klimatu, w którym teologowie rozbudowują dziś międzyosobowy aspekt religijnego stosunku wiary, obudzonego przez Słowo Boże". - To podejście w teologii ocenia Congar zasadniczo pozytywnie (nie tylko zresztą on sam). „Harmonizuje (bowiem) z postulatami wyrastającymi z odnowy biblijnej. Z pewnością teologia wiary i religijnych związków z Bogiem może wyciągnąć korzyści z nowoczesnych refleksji nad egzystencją ludzką i międzyosobowym związkiem Ja-Ty" 14. Podobnie pisał, w nawiązaniu do B. Lamberta, OP Kardynał Kominek: „Kiedyś nacisk kładziono bardziej na porządek obiektywny, starano się rozumieć nadprzyrodzoną rzeczywistość raczej od strony Boga. Teraz próbuje się więcej wmyśleć w sytuację człowieka i analizując jego otoczenie, usiłuje się jakby indukcyjnie z tego usytuowania człowieka robić drabinę, po której człowiek wspinałby się ku Bogu"15.

14 Y. M. Congar, Chrystus w ekonomii zbawienia, „Znak”, XIX (1967), 1362, 1369.

is Bolesław Kominek, Główne tendencje we współczesnej teologii, „Studia Theologica Varsaviensia”' 7 (1969, nr 2) 45. 
To podejście antropologiczne niewątpliwie ubogacające - na co jeszcze zostanie zwrócona uwaga - stało się koniecznością i zadaniem dla teologii. Stało się koniecznością, bowiem rozumienie człowieka dokonuje się dzisiaj przede wszystkim w kategorii podmiotu, przeciwstawionej kategorii rzeczy (przedmiotu). „Bez ontologii podmiotu, teologia łaski, a wraz z nią cała teologia pozostaje w sferze wyobrażeń preteologicznych", i nie jest zdolna odpowiadać na pytania współczesnego człowieka, „czy mówienie o przebóstwieniu, usynowieniu, mieszkaniu Boga, itd. nie stanowi pojęciowej poezji i nie jest nieudowadnialnym mitem" ${ }^{16}$. - To podejście antropologiczne jest także zadaniem współczesnej teologii, która winna zdać sprawę w płaszczyźnie rozumowej, poznania z dzisiejszego świadectwa wiary Kościoła. Otóż, jak stwierdza H. de Lubac, „dwa słowa (tj. antropologia chrześcijańska) najlepiej streszczają główny cel Konstytucji Gaudium et spes". W związku zaś z tym wyraża on przekonanie, ,że zasady wyrażone tam staną się natchnieniem dla niejednego studium teoretycznego [...] przyspieszą one dojrzewanie »antropologii chrześcijańskiej«, której tak potrzebuje nasze stulecie" ${ }^{17}$.

Znaczenie tego kierunku dla teologii jest widoczne zarówno pod względem formalnym jak i merytorycznym. a) Pod względem formalnym: dawna teologia ujmowała niejedno zagadnienie (np. działania Bożego, łaski na sposób zreizowany, „urzeczowiony” (poprzez kategorie rzeczy). Na tej drodze pewne problemy, jak np. próba wyjaśnienia wolności człłowieka w odniesieniu do przyczynowego działania Bożego pojętego w kategoriach kosmologicznych (tp. w pojęciach zaczerpniętych ze świata rzeczy natury) - jak to ukazuje A. Dondeyne - nie tylko nie mogły zostać właściwie rozwiązane, ale prowadziły do rozwiązań pozornych a nawet błędnych ${ }^{18}$. Obecna teologia uwzględniająca specyfikę podmiotu, specyfikę bytu duchowego, może bardziej adekwatnie zdać sprawę

16 K. Rahner, Teologia a antropologia, ,Znak”, XXI (1969) 1936, 1543.

17 Henri de Lubac, Ateizm i sens człowieka, Paris 1969, 10.

18 Dondeyne zwraca $m$. in. uwagę na to, że jeśli Boga traktowało się jako Ens realissimum, Rzeczywistość Nieskończoną tego rodzaju, iż wszystko się w Nim zawiera od wieków (tak jak to ma miejsce w przyczynowości naturalnej) - stanowisko reprezentowane przez kierunek banezjański - łącznie z naszymi decyzjami wolnymi i osobowymi, to wtedy też trudno jest odpowiedzieć na zarzut Fr. Jeansona o przekształceniu na tej drodze egzystencji ludzkiej w przeznaczenie. - L'athéisme contemporain et le problème des attributs de Dieu, w: Foi et réflexion philosophique, Louvain 1961, 475. - W tym samym duchu pisał Kardynał Kominek: „Spośród wielu przykładów wymieńmy, jak w związku z tym statycznym, ułożonym porządkiem kosmicznym teologia ujmowała niejedno zagadnienie mechanicznie, instrumentalnie - na sposób zreizowany i ,urzeczowiony”. Semmelroth mówi wyraźnie o apersonalistycznym przedstawieniu poszczególnych traktatów teologicznych: naukę o Bogu, o zbawczym oddziaływaniu Chrystusa, o lasce, o Kościele. Zamiast pokazywać pośrednictwo zbawienia w jego personalistycznej ludzkiej głębi, zrobiono z łaski rzecz - RES. Sommelroth mnoży wyrażenia: Vergegenstänlichung, Versachlichung, Verdinglichung. Nic więc dziwnego, że nowa teologia stara się na nowo odnaleźć pierwiastki osobowe, osobowościowe, bardziej dostępne i przemawiające do współczesnego człowieka”. - art. cyt. wyżej, 46-47. 
z właściwych treści posłannictwa chrześcijańskiego. b) Przykładowo więc, za M. Nédoncellem, wskażmy na niektóre merytoryczne rozwiązania, które ze sobą niesie tak zorientowana teologia. „Dopóki będziemy przedstawiać śmierć jako rozdzielenie duszy i ciała, teologia krzyża pozostanie dla nas uboga i sucha. Jeżeli natomiast postaramy się zgromadzić i pogłębić doświadczenie ludzkie z tym związane, jak to na różne sposoby czynili Landsberg, Karl Rahner i Mouroux, sens Odkupienia zabłyśnie nowym światłem. Rozmyślania nad śmiercią człowieka, jakąkolwiek byłaby ta śmierć i kimkolwiek byłby ów człowiek, dodają bodźca i pozwalają spojrzeć na śmierć Chrystusa $z$ nowego punktu widzenia [...]. Nikt nie zaprzeczy, że głębsza znajomość macierzyństwa może przyczynić się do lepszego teologicznego ujęcia pewnych aspektów mariologii. - Gnothi seauton włączone w program filozofii stawia w nowym świetle nie tylko naturę ludzką Chrystusa czy Maryi; oddaje jeszcze większe usługi, wyjaśnia istotę i dzieło Słowa wcielonego. Dokładniejsze badania nad solidarnością ludzką nie mogą nie mieć wpływu na nasze badania tajemnicy Wcielenia [...]. Całość nauki o sakramentach również wiele zawdzięcza antropologii. Przede wszystkim w znaczeniu ogólnym, gdyż pojęcie aktu duchowego i znaku jest nierozłączne z sakramentem. Scholastycy, dyskutując nad materią i formą, nieraz pozostawiali na boku lub też przesuwali na drugi plan intentio, o której przecież wiele mówiono na Soborze Trydenckim [...]. Jeżeli rozpatrzymy teraz poszczególne sakramenty, narzucają nam się te same refleksje. [...] Np. do nadprzyrodzonego pojmowania małżeństwa pomocą jest filozoficzne rozważanie miłości. Wielu współczesnych myślicieli usiłowało to udowodnić, często z dobrym wynikiem [...]”. Podsumowując M. Nédoncelle stwierdza: ,że istnieje kierunek filozoficzny (zarówno w aspekcie fenomenologicznym, jak i metafizycznym), zbliżony do antropologii, lecz nie stanowiący zwykłego wprowadzenia do teologii Objawienia, natomiast zajmujący $w$ niej miejsce, jakby część $z$ góry przeznaczoną. W tym aspekcie nadprzyrodzoność stanowi istotnie wywyższoną naturę i nic więcej [...]. Czy można przeczyć temu, że antropologia znajduje swe miejsce w teologii i przez pewnego rodzaju prostą transpozycję przystosowuje się do nowego porządku rzeczy? Usprawiedliwia to fakt, że Chrystus był człowiekiem. Pierwiastek ludzki da się bezpośrednio włączyć w perspektywę teologiczną przez to, że jest bardziej ludzka niż nasza, gdyż jest doskonalej ludzka niż nasza" 19.

Jak z tego przedstawienia można wnosić, orientacja antropologiczna ma swój szczególnie duży udział w kształtowaniu współczesnej teologii. Nic też dziwnego, że ostatni Kongres Teologów Polskich odbyty w Lubli-

19 Art. cyt., 452-454. 
nie, w 1971 r. podjął problematykę ,Teologia a antropologia” jako główny temat swych obrad ${ }^{20}$.

\section{Zwrot fenomenologiczny}

Wiąże się on na swój sposób $\mathrm{z}$ podejściem antropologicznym. Zanim postawi się pytanie o ostateczny fundament, pytanie metafizyczne, o byt w sobie, trzeba poznać, czym jest to, co jest nam bezpośrednio dane, fenomen. W tym podejściu, mówiąc o przedmiocie nie można pominąć podmiotu. Zasadniczym postulatem, który został tutaj wysunięty, to domaganie się, aby wszelkie założone struktury sensu odnieść do pierwotnych danych (do doświadczenia pierwotnego), które je wyznaczają, i by wszelkie znaczenia ujmować w ich pierwotnych ustanowieniach (pierwotne znaczenie językowe) ${ }^{21}$. Zasadnicze wyjaśnienie może się dokonywać tylko w ten sposób, że podstawowe treści będą poszukiwane w swojej pierwotności, z niej będą zaczerpnięte, tak, że nic do tej pierwotnej zawartości treści nie będzie dodane. - Musimy wiedzieć, co myślimy mówiąc natura, historia, zanim będziemy mogli iść w kierunku dalszego wyjaśnienia. Chodzi właśnie o wyjaśnienie tego początkowo pomyślanego z niego samego albo z jego pierwotnie danych. Oznacza to zarazem powrót do tych początków i podstaw, z których wyrastają podstawowe określenia nauk 22 .

Postulat ten uznany jako bezsporny dla każdej nauki, odniesiono również do nauki o religii w ogóle, i do nauk teologicznych. Także i w teologii należy najpierw pytać skąd pochodzą podstawowe treści znaczeniowe, zanim podejmie się ich tłumaczenia w kategoriach ontologicznych. Zasadnicza zmiana orientacji w stosunku do dawnej teologii polegała tutaj na tym, że chcąc oddać umysłowo poznawalnymi ukonstytuowane dogmaty, nie bierze się ich jako punktu wyjścia dla spekulacji metafizycznej, lecz jako punkt dojścia świadomości religijnej ${ }^{23}$. Oddać umysłowo poznawalna treść nie znaczy więc w tym podejściu wyjaśnić ją przy pomocy kategorii filozoficznych, ale przeciwnie pozwolić, by ona sama wyjaśniała, żywiła myśl filozoficzną ${ }^{24}$. Jakkolwiek słuszny był ten postulat, wkrótce jednak przekonano się, że nie można obyć się bez ontologii, bez metafizyki ${ }^{25}$. Powiem o tym jeszcze w ostatnim punkcie.

20 Zob. Teologia a Antropologia, Kongres Teologów Poiskich 21-23 IX 1971, Kraków, bez daty.

21 Por.: B. Welte, dz. cyt., 25.

22 Por. B. Welte, Der Gottesbeweis und die Phänomenologie der P...yion, w: Auf der Spur des Ewigen, Freiburg-Basel-Wien 1965, 315-316.

${ }_{23}$ Por. G. van Riet, $\mathrm{Y}$ a-t-il chez saint Thomas une philosophie de la religion?, w: Philosophie et Religion, Louvain 1970, 104. - Zob. równ. M. Jaworski, Problem filozofii religii, ,Studia Philosophiae Christianae”, 2 (1967) 187.

24 G. van Riet, j. w., 105. 
Zwrot fenomenologiczny, o którym mowa, odbił się następująco na teologii:

$1^{\circ}$ towarzyszył mu nawrót do Biblii, Ojców Kościoła, liturgicznego kultu. Dążono do oczyszczenia treści Chrześcijaństwa z naleciałości, balastu i przerostu filozoficznego, a starano się doszukać jego najbardziej autentycznej i pierwotnej treści. Stąd $m$. in. prace tego rodzaju jak K. Adama Istota Chrześcijaństwa, czy R. Guardiniego Wesen des Christentums.

$2^{\circ}$ pomógł wyznaczyć właściwą rolę i udział refleksji filozoficznej w teologii. Refleksja filozoficzna musi bowiem uwzględniać owe pierwotne, pozytywne dane religijne, chcąc je oddać zrozumialnymi przy pomocy kategorii ludzkiej myśli ${ }^{26}$. O zmianie tej jest mowa m. in. w Liście Kongregacji, choć nie wspomina on na jakiej zasadzie dokonało się to w teologii: „Prymat [badania źródeł Objawienia jak również przekazywania ewangelicznego posłania na przestrzeni stuleci] nie podlega dyskusji i nie należy żadną miarą go podważać. Odrzucić trzeba tak samo niewłaściwe próby wprowadzenia filozofii w dziedzinę nauki objawionej. Jednakowoż w obecnej chwili, kiedy faktem jest osiągnięcie równowagi i dokonanie poważnych postępów w naukach biblijnych, a także na pewnych odcinkach teologii pozytywnej, możliwe staje się i konieczne uzupełnienie i ukoronowanie tej pracy historycznej racjonalną refleksją nad danymi objawienia".

$3^{\circ}$ przez podkreślenie znaczenia doświadczenia przyczynił się podobnie jak to miało miejsce w filozofii - do przezwyciężenia tzw. teologii pojęciowej, w złym znaczeniu abstrakcyjnej, a więc takiej, w której nastąpiło oderwanie się od rzeczywistości, a samo pojęcie traktuje się jako rzeczywistość ${ }^{27}$. - Nowa teologia, chcąc oddać właściwy sens pojęć teologicznych została skierowana $\mathrm{w}$ ten sposób przede wszystkim na doświadczenie chrześcijańskie, na historię świętą, historię wkroczenia Boga w świat i stanowiącego w ten sposób „Boga-z-nami”, nobiscum Deus ${ }^{28}$.

Niewątpliwie do tego rodzaju uprawiania teologii wzywał Papież Paweł VI w swej Encyklice Ecclesiam suam, kiedy jako zadanie postawił pełniejsze samookreślenie się Kościoła, poprzez dążenie „do nabycia jaśniejszej świadomości tego, czym on jest sam” ... (p. 18), ,... do wyraźniejszej znajomości tego, czym w rzeczywistości (podkr. moje) jest według myśli Jezusa Chrystusa, zawartej w nieskażonej całości w Piśmie św. i apostolskiej tradycji [...]" (p. 26).

25 Por. B. Welte, Heilsverständnis..., 23-24.

26 Por. B. Welte, Heilsverständnis..., 23-24.

27 Por. M. Jaworski, Negacja sensowności idei Boga we współczesnych kierunkach ateizmu, „Ateneum Kapłańskie”, Z. 3-386 (1973), 342.

28 Por. A. Dondeyne, L'athéisme..., 473-474. 


\section{Fenomenologia egzystencjalna}

Nie ulega najmniejszej wątpliwości, że refleksja nad istnieniem, losem ludzkim — charakterystyczna dla dzisiejszej myśli filozoficznej — o której pisał cytowany wcześniej Congar — swój przemożny wyraz znalazła w tzw. fenomenologii egzystencjalnej. To właśnie fenomenologia egzystencjalna ,przyjmuje jako swój fakt pierwotny, intuicję fundamentalną, wszechogarniający moment zrozumiałości, pojęcie egzystencji [...]" 29.

Wiadomą rzeczą jest również, że refleksja teologiczna - zwłaszcza w pewnych kręgach na Zachodzie - w dużej mierze została zdeterminowana przez ten kierunek współczesnej myśli filozoficznej. Nie przypadkowo Katechizm Holenderski swoją pierwszą część poświęca Istnieniu jako tajemnicy (w tłumacz. niemieckim: Das Dasein - ein Geheimnis). W ten sposób i dla twórców katechizmu holenderskiego pojęcie egzystencji stanowi wszechogarniający moment zrozumialności Chrześcijaństwa.

Nie jest zadaniem tego referatu poddawanie krytycznej ocenie rezultatów, jakie w poszczególnych dziedzinach teologii przyniosło zastosowanie tego kierunku ${ }^{30}$. Ocena ta należy do teologów. Ze swej strony wypada jednak zwrócić uwagę na pewne momenty, które na tym odcinku mogą rozjaśnić wytworzoną sytuację w teologii.

Istnieją odmiany myśli egzystencjalno-fenomenologicznej, i nic nie upoważnia nas do ograniczenia otwartości podmiotu tylko na świat (tak jak to jest w egzystencjalizmie ateistycznym) i negowaniu jego orientacji ku Bytowi Transcedentnemu. Wydaje się, że niewolnicze trzymanie się jednej odmiany fenomenologii egzystencjalnej (Heideggera), implikującej określoną teorię bytu, przyczyniło się, przy korzystnym rozbudowaniu religijnej egzystencji człowieka gdy chodzi o stosunki międzyosobowe, do częściowego zapoznania podstawowego charakteru jego otwartości (wymiar wertykalny), a także do przeakcentowania historycznego horyzontu bytu i prawdy. (Należy spodziewać się, że teologowie będą dążyć do wyrównania niewątpliwych braków, które w ten sposób zaistniały).

Sam jednak kierunek fenomenologii egzystencjalnej - który jest sposobem określonego stylu myślenia naszej epoki - może mieć, jak pisze Congar, swoje dodatnie znaczenie dla refleksji teologicznej. Zresztą pod wieloma względami ma to już miejsce. Dzieje się zaś tak dlatego, że samo chrześcijaństwo nosi charakter egzystencjalny, który oczywiście implikuje szczególną metafizykę, niemniej nie znosi ona jego charakteru egzystencjalnego. Wyraża się on już w samym języku Objawienia.

Język biblijny jest językiem konkretnej egzystencji, egzystencji reli-

29 William A. Luijpen, Fenomenologia egzystencjalna, Warszawa 1972, 41.

30 Por. Ks. Ignacy Różycki, Początki ,nowej” teologii, „Studia Theologica Varsaviensia" 7 (1969, $\mathrm{nr}$ 2) 49-103. 
gijnej, opisem doświadczenia religijnego. Mówi on o Bogu, Chrystusie przede wszystkim w odniesieniu do człowieka. Wypowiedzi te zawierają jednak w sobie lub stanowią wy jście ku temu co ontologiczne (Congar) ${ }^{31}$.

Ten dobrze rozumiany egzystencjalny charakter Objawienia podkreśla również m. in. P. Benoit: „Prawda objawiona w Biblii jest konkretna, osobista, całkowita, jest prawdą życia. To co Bóg odkrywa przez Biblię człowiekowi, nie jest prawdą abstrakcyjną, czystą spekulacją, do której skłaniał się pewien rodzaj filozofii greckiej. Jest to prawda życia, raczej egzystencjalna, niż esencjalna, jeśli przyjmiemy poprawną interpretację tych terminów" 32 .

$\mathrm{Na}$ egzystencjalny charakter Objawienia judeo-chrześcijańskiego i pierwszych wieków chrześcijaństwa zwraca uwagę także J. C. Murray, twierdząc, że w epoce patrystycznej - na skutek kontrowersji ariańskiej i Eunomiusza - problem Boga został przeniesiony na nową płaszczyznę. Z określeń intersubiektywnych i opisowych został on przeniesiony na określenia ontologiczne i definicje ${ }^{33}$.

Odwołując się do interpretacji egzystencjalnej możemy więc i dzisiaj lepiej rozumieć pierwotny charakter Objawienia, albo możemy, jak pisał Congar, ponownie otworzyć pewien rozdział myśli ludzkiej. Przyzwyczajonym do interpretacji klasycznych, a więc w kategoriach ontologicznych trudno nieraz uchwycić właściwy sens nowych interpretacji, będących w innej płaszczyźnie i w innym języku. Warto jednak tutaj dodać, że niektóre nowe kategorie interpretacji zostały już przyjęte przez Nauczycielski Urząd Kościoła (np. w nauce o Eucharystii).

W związku z tym należy postawić problem właściwego podejścia do tego rodzaju nowych interpretacji, by uniknąc nieporozumień $\mathrm{w}$ tym względzie i zdobyć właściwe rozeznanie. Pomijając na razie kryterium wiary, podstawowy sens twierdzeń wiary, który wyznacza Magisterium Ecclesiae, trzeba zdawać sobie dobrze sprawę z tego, że interpretacja w płaszczyźnie egzystencjalnej różni się zasadniczo od płaszczyzny interpretacji metafizycznej. Tym samym nie można zastąpić języka jednej interpretacji językiem drugiej interpretacji, czy też stawiać ich na równi. Teolog-metafizyk nie może mieć pretensji, że teolog-fenomenolog daje inną interpretację niż on, ale i teolog-fenomenolog nie może odrzucać interpretacji metafizycznej, jeśli „stosunek wiary i zbawienia ma być oparty na prawdzie. Interpretowanie wypowiedzi Pisma św. w kategoriach bytu jest zjawiskiem normalnym, bo takie są prawa umysłu, takimi Bóg nas stworzył i powołał do wiary. Nie można uniknąć pytań doty-

31 Y. M. Congar, Chrystus w ekonomii..., 1370-1371.

32 Pierre Benoit, Natchnienie $i$ Objawienie, „Concilium”, Poznań-Warszawa 1965/6, 695. - Por. równ. M. Jaworski, Teologia a antropologia, 60-63.

${ }_{33}$ J. C. Murray, Le problème de Dieu de la Bible à l'incroyance contemporaine, Paris 1965, 14. 
czących bytu, bo nie można uniknąc myślenia o tym, czym są rzeczywistości, o których Słowo Boże coś twierdzi" ${ }^{34}$. Problemem dzisiaj jest na pewno nie alternatywa ,albo-albo", ale komplementarność i powiązanie obu rodzajów interpretacji.

W ten sposób przychodzimy do następnego i ostatniego punktu naszych rozważań, do udziału refleksji filozoficznej, typu metafizycznego $\mathrm{w}$ teologii.

\section{Metafizyka a teologia}

Zarówno we współczesnej myśli filozoficznej jak i teologicznej, kładącej nacisk na to, co jest pozytywnie i bezpośrednio dane, szybko dostrzeżono, że nie można obyć się bez ,światła bytu”, i że to co jest dane zostaje zawsze ujęte poprzez tematyzację bytu, którą człowiek posiada w danym okresie. Każdy przekaz implikuje w ten sposób określone kategorie ludzkiego rozumienia. Na tego rodzaju implikację ontologii wskazują dziś m. in. Heidegger, Rahner, Tillich. Także Barth w swych ostatnich wydaniach dogmatyki zmuszony został do stwierdzenia, że teologia nie może się obejść bez tego rodzaju refleksji filozoficznej ${ }^{35}$.

Teologia nie może obyć się bez metafizyki, filozofii bytu, chodzi bowiem ostatecznie o prawdę rzeczy. Bez metafizyki, bez analogia entis nie ma mowy o Bogu, o teologii w ścisłym tego słowa znaczeniu, bo nie może być mowy o właściwej transcedencji bytu Bożego. Możliwa jest tylko tzw. teologia śmierci Boga i okaleczona, błędna Chrystologia. Ta ostatnia także do pewnego czasu, albowiem - jak zaznacza $\mathrm{m}$. in. H. U. v. Balthasar - wraz ze śmiercią metafizyki niepostrzeżenie likwiduje się w praktyce również nauki humanistyczne, które są rozumieniem wolnego ducha ludzkiego ${ }^{36}$.

Poznanie więc metafizyczne jest nieodzowne dla teologii i to przede wszystkim z dwóch racji: $1^{\circ}$ bez poznania prawd, które określa się jako praeambula fidei, a zwłaszcza bez poznania istnienia jedynego Boga, cała prawda Objawienia chrześcijańskiego jest podstawowo niezrozumiała. Co więcej, jeśli się dobrze zastanowimy, jest ona w ogóle niemożliwa do przyjęcia. W miejsce bowiem metafizyki (mniej lub więcej krytycznie wypracowanej) przyjmującej istnienie Boga a wraz $z$ tą prawdą inne prawdy dotyczące człowieka i świata, wkracza automatycznie metafizyka inna, która jest nie do pogodzenia z treścią Objawienia chrześcijańskiego.

34 Y. M. Congar, Chrystus w ekonomii..., 1371.

3.5 Por. B. Welte, Heilsverständnis..., 23. - Welte odsyła tutaj także czytelnika do: H. U. von Balthasar, Karl Barth, Darstellung und Deutung seiner Theologie, Köln-Olten 1951. - Zob. równ. Y. M. Congar, Chrystus w ekonomii..., 1370-1371.

36 H. U. von Balthasar, Spotkanie z Bogiem w świecie dzisiejszym, „Concilium”, 1965/6, 422 . 
W konsekwencji teologia nie może się obyć bez Boga filozofów. Zostaje On w niej utrzymany i wywyższony. $2^{\circ}$ reflekcja metafizyczna odgrywa też szczególną rolę w samej teologii, a zwłaszcza teologii Trójcy św., a wraz z nią w całej Chrystologii. Nie sposób tego udziału omawiać tutaj bliżej, należy to zresztą do teologów. Wiadomo skądinąd, że niektóre współczesne poglądy teologiczne dotyczące osoby Jezusa Chrystusa które musiały budzić zastrzeżenia Urzędu Nauczycielskiego Kościoła zostały uwarunkowane pewnego typu metafizyką (ujmującą byt wyłącznie w "horyzoncie czasowym") ${ }^{37}$.

W związku z tym rodzi się pytanie o rodzaj metafizyki, która współcześnie wysuwa się na czoło i wywiera swój wpływ na teologię. Nie ulega wątpliwości, że jest to filozofia bytu Heideggera, który zaatakował ostro - w jego mniemaniu całą — dotychczasową metafizykę Zachodu. (Nb. prawie jedynym i bardzo często cytowanym nazwiskiem na Kongresie Tomistycznym w Rzymie, gdy chodzi o problematykę bytu było nazwisko Heideggera, którego myśl na tym odcinku konfrontowano z myślą św. Tomasza). Filozofia bytu Heideggera została w różny sposób zużytkowana w teologii (teologowie holenderscy, K. Rahner, nawiązujący również do kierunku filozofii transcendentalnej). W tym nastawieniu teologów było dużo reakcji przeciwko rozmaicie pojętemu tomizmowi. (Przejawiało się to także na Soborze Watykańskim II). Ta sytuacja nie wydaje się obecnie stanowić przeważającej tendencji. Congar słusznie zauważa, że obecnie niektóre prace — być może na zasadzie krytyki dotychczasowych interpretacji — „odtwarzają nam oryginalne reakcje św. Tomasza, jego najbardziej twórcze spostrzeżenia, głębsze i bardziej otwarte, a także bardziej interesujące ze współczesnego punktu widzenia, niż można było mniemać na podstawie lektury klasycznych komentatorów tomizmu i podręczników" 38.

Potwierdzeniem tego stanu rzeczy były wypowiedzi wielu czołowych teologów z różnych kręgów i środowisk na ostatnim Międzynarodowym Kongresie Tomistycznym w Rzymie. Gdy chodzi zaś o filozofię bytu

37 Edith Stein w swej rozprawie: Martin Heideggers Existentialphilosophie, zam. w VI t. jej dzieł pt. Welt und Person, Louvain 1962, zaznacza, że u Heideggera wszystko skierowane jest na to, by dowieść czasowości bytu. Następstwa zaś tego są bardzo ważkie. Oto, co pisze ona na ten temat: ,Darum wird überall ein Riegel vorgeschoben, wo sich ein Ausblick zum Ewigen öffnet; darum darf es kein vom Dasein unterschiedenes Wesen geben, das sich im Dasein verwirklicht; darum keinen vom Verstehen unterschiedenen Sinn, der im Verstehen erfasst wird; darum keine vom menschlichen Erkennen unabhängigen ewigen Wahrheiten — durch all das würde ja die Zeitlichkeit des Seins gesprengt, und das darf nicht sein, mögen auch Dasein, Verstehen und Entdecken noch so sehr zu ihrer eigenen Klärung nach etwas von ihnen selbst Unabhängigem, Zeitlosem verlangen, was durch sie und in ihnen in die Teitlichkeit eingeht". - Sam Heidegger określał ,ewigen Wahrheiten” jako ,zu den längst noch nicht radikal ausgetriebenen Resten von christlicher Theologie innerhalb der philosophischen Problematik". - 114.

38 Y. M. Congar, Teologia na Soborze, 31-43. 
św. Tomasza, to J. B. Lotz wykazał nie tylko w jakiej mierze zarzut Heideggera wysuwany pod adresem metafizyki Zachodu nie dotyczy Akwinaty, ale ponadto pokazał, jak św. Tomasz dochodzi do tej ostatecznej głębi bytu, której sam Heidegger nie wyciągnął z zapomnienia (ograniczenie się tylko do ,horyzontu” czasowego bytu) ${ }^{39}$.

\section{PODSUMOWANIE I WNIOSKI KOÑCOWE}

1. Tradycja katolicka, potwierdzona przez Sobór Watykański II, a ostatnio przez cytowany już kilkakrotnie list Kongregacji dla Wychowania Chrześcijańskiego domaga się odpowiedniej formacji filozoficznej dla kapłanów, jako nieodzownej dla autentycznej refleksji teologicznej. Rozważania przeprowadzone w tym referacie w oparciu o tę zasadę, na swój sposób starały się ukazać wzajemne przenikanie filozofii i teologii w naszych czasach.

2. Współczesna refleksja teologiczna winna umiejętnie korzystać z rozwoju myśli filozoficznej. Tylko w ten sposób może spełnić ona swoje zadanie (Por. Dekret Optatam totius i List Kongregacji). - Ustosunkowanie się do kierunków filozofii klasycznej - zwłaszcza metafizyki św. Tomasza - i do współczesnych kierunków filozoficznych — jak zostało to zaznaczone w trakcie rozważań - nie może być alternatywne, wykluczające, ale komplementarne. Zakładając, że chodzi o prawdę a nie o system, trzeba iść śladami św. Tomasza, który - jak pisze O. Geiger wykazuje pierwiastki platońskie w jego myśli, powinien był wybrać, ale nie wybrał. ,Nie jest ani platonikiem ani arystotelikiem — jest jednym i drugim" 40. Josef Pieper, nawiązując do tej charakterystyki św. Tomasza, doda, że cechowała go ,zdolność opanowania, asymilacji, która niczego nie wykluczała, niczego nie opuszczała, a polegała na tym, że wszystko, co istnieje, »tu się mieści«, na przykład zarówno Biblia, jak i metafizyka Arystotelesa" 41. André Hayen stwierdzi zaś, że podjął on ten niesłychany wysiłek ,by brać wszystko" 42.

3. Nie oznacza to rezygnacji z filozofii chrześcijaństwa. Istnieje problem filozofii chrześcijańskiej - ale jakkolwiek on będzie rozwiązywany przez myślicieli chrześcijańskich - nie narusza to w niczym faktu filozofii chrześcijaństwa, którą ono zawiera w sobie jako podstawowe praw-

3) Lotz J. B., Das Sein nach Heidegger und Thomas von Aquin, w: Tommaso D'Aquino nel suo VII centenario, Congresso Internationale, Roma-Napoli, 17-24 Aprile 1974, 321.

s0 L. B. Geiger, La participation dans la philosophie de St. Thomas d'Aquin, Paris 1942, 31. - Cyt. za: J. Pieper, Tomasz z Akwinu, Kraków 1966, 21.

41 Dz. cyt., j. w., 22.

42 André Hayen, Thomas gestern und heute, Frankfurt 1954, 62. - Cyt. za Pieperem, j. w., 21. 
dy filozoficzne - rozumowe, choć nie zdobyte na drodze rozumowej ani też wyrażone językiem filozoficznym. W tym też sensie nie tylko dla filozofii chrześcijańskiej - jak stwierdza Gilson - ale i dla teologii „,nieomylnym przewodnikiem pozostanie zawsze wiara” ${ }^{43}$. W niej bowiem odnajdzie teologia właściwe kryterium wyboru filozofii jako swego narzędzia.

43 E. Gilson, Filozof $i$ teologia, Warszawa 1968, 207.

\section{LES COURANTS PHILOSOPHIQUES LEGITIMANT LA NOUVELLE THEOLOGIE}

\section{$\mathrm{R}$ és u mé}

L'auteur présente le problème mentionné dans quatre paragraphes.

Le premier paragraphe traite de la part de la philosophie dans la théologie. Le seul mot de "théologie" fait déduire qu'elle-même se constitue grace à la philosophie. Pas de théologie sans philosophie! Il faut faire attention à deux facteurs conditionnant la mise en question de la participation de la philosophie dans la théologie: 1. l'identification de la manière impropre de la participation de la philosophie dans la théologie avec la participation de la philosophie en général; 2. la compréhension plus ou moins idéaliste de la philosophie.

Le second paragraphe aborde le problème de la diversité et du développement de la réflexion philosophique dans son rapport à la théologie. Le pluralisme philosophique mène à la création de divers courants théologiques, tandis que le développement de la réflexion philosophique à la compréhension progressive de la foi. Le deuxième moment est bien montré par l'exemple d'une meilleure compréhension actuelle de la dimension historique de l'existence humaine.

Le troisième paragraphe présente certains courants philosophique qui ont leur part dans la formation de la théologie contemporaine, à savoir: 1. anthropologie; 2. phénoménologie; 3. phénoménologie existentielle; 4 . métaphysique. Il est aussi dit ce que chaque orientation a apporté de nouveau à la théologie et en quoi consiste son enrichissement.

Le quatrième paragraphe résume les réflexions et donne les conclusions finales. Ces observations montrent la compénétration réciproque de la philosophie et de la théologie de notre temps. Par rapport à la philosophie classique et à la philosophie contemporaine, la théologie ne peut prendre ou l'une ou l'autre, mais toutes les deux, parce qu'elles sont complémentaires. Il y a de même le problème de la philosophie chrétienne: les vérités rationelles contenues dans le christianisme - révélées ou pas encore exprimées en langage philosophique. Là, la théologie trouve le propre critère du choix d'une philosophie comme son critère. 